\title{
The aqueous extract of Albizia adianthifolia leaves attenuates 6-hydroxydopamine- induced anxiety, depression and oxidative stress in rat amygdala
}

Galba Jean Beppe $e^{1,3^{*}}$, Alain Bertrand Dongmo², Harquin Simplice Foyet ${ }^{3}$, Théophile Dimo ${ }^{1}$, Marius Mihasan ${ }^{4}$ and Lucian Hritcu ${ }^{4 *}$

\begin{abstract}
Background: While the Albizia adianthifolia (Schumach.) W. Wright (Fabaceae) is a traditional herb largely used in the African traditional medicine as analgesic, purgative, antiinflammatory, antioxidant, antimicrobial, memory-enhancer, anxiolytic and antidepressant drug, there are no scientific data that clarify the anxiolytic and antidepressant-like effects in 6-hydroxydopamine (6-OHDA)-lesioned animal model of Parkinson's disease. This study was undertaken in order to identify the effects of aqueous extract of A. adianthifolia leaves on 6-hydroxydopamine-induced anxiety, depression and oxidative stress in the rat amygdala.
\end{abstract}

Methods: The effect of the aqueous extract of A. adianthifolia leaves (150 and $300 \mathrm{mg} / \mathrm{kg}$, orally, daily, for 21 days) on anxiety and depression was assessed using elevated plus-maze and forced swimming tests, as animal models of anxiety and depression. Also, the antioxidant activity in the rat amygdala was assessed using assessed using superoxide dismutase, glutathione peroxidase and catalase specific activities, the total content of the reduced glutathione, protein carbonyl and malondialdehyde levels. Statistical analyses were performed using by one-way analysis of variance (ANOVA). Significant differences were determined by Tukey's post hoc test. F values for which $p<0.05$ were regarded as statistically significant. Pearson's correlation coefficient and regression analysis were used in order to evaluate the connection between behavioral measures, the antioxidant defence and lipid peroxidation.

Results: 6-OHDA-lesioned rats exhibited the following: decrease of the exploratory activity, the percentage of the time spent and the number of entries in the open arm within elevated plus-maze test and decrease of swimming time and increase of immobility time within forced swimming test. Administration of the aqueous extract significantly exhibited anxiolytic- and antidepressant-like effects and also antioxidant potential in the rat amygdala.

Conclusions: Our results suggest that the aqueous extract ameliorates 6-OHDA-induced anxiety and depression by attenuation of the oxidative stress in the rat amygdala. These pieces of evidence accentuate its use in traditional medicine.

Keywords: Albizia adianthifolia leaves extract, 6-hydroxydopamine-lesioned model, Anxiolytic-like effect, Antidepressant-like effect, Parkinson's disease

\footnotetext{
* Correspondence: galbajeanbeppe@yahoo.com; hritcu@uaic.ro

'Laboratory of Animal Physiology, Faculty of Science, University of Yaoundé I,

PO Box, 812, Yaoundé, Cameroon

${ }^{4}$ Department of Biology, Alexandru loan Cuza University of lasi, Bd. Carol I,

No. 11, lasi, Romania

Full list of author information is available at the end of the article
}

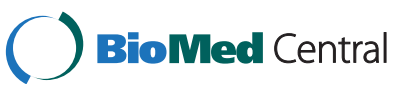

(c) 2015 Beppe et al. Open Access This article is distributed under the terms of the Creative Commons Attribution 4.0 International License (http://creativecommons.org/licenses/by/4.0/), which permits unrestricted use, distribution, and reproduction in any medium, provided you give appropriate credit to the original author(s) and the source, provide a link to the Creative Commons license, and indicate if changes were made. The Creative Commons Public Domain Dedication waiver (http://creativecommons.org/publicdomain/zero/1.0/) applies to the data made available in this article, unless otherwise stated. 


\section{Background}

Parkinson's disease (PD) is a neurodegenerative disorder characterized by a massive and progressive degeneration of the dopaminergic neurons in the substantia nigra (SN) [1]. About 30-40 \% of people with PD experience a depressive disorder [2] and most have symptoms of depression at some stage [3]. Up to $40 \%$ have symptoms of anxiety and around $30 \%$ experience an anxiety disorder [4]. About $40 \%$ of people with PD and depression also have an anxiety disorder. The link between PD, depression and anxiety is complex. Its neuropathology includes the degeneration of dopaminergic nigrostriatal pathway, which is a cumulative effect of glutathione depletion, iron deposition, increased lipid peroxidation, oxidative DNA damage, mitochondrial dysfunction, excitotoxicity and alterations in antioxidant enzymes activities $[5,6]$.

Previous studies indicated the role of the amygdala in regulating anxiety, depression responses and fear memory in both humans and animals [7]. Furthermore, the dopamine neurotransmitter system is involved in a large number of higher brain functions, and regulates the activity of the amygdala [8].

The most widely used animal models of PD involve intracranial infusion of the neurotoxin 6-OHDA directly into the ascending dopaminergic forebrain bundle, thereby inducing severe dopaminergic neuronal degeneration associated with profound deficits in feeding, drinking, sensorimotor and learning functions $[9,10]$.

Oxidative stress mechanism gets more prominent in the process of ageing, thus is the most important risk factor for developing PD [11]. Mitochondrial dysfunction along with damaged proteins and lipids due to oxidative stress plays a key role in PD pathological process [12].

$A$. adianthifolia is a medicinal plant widely distributed in Africa and in Cameroon. Aqueous and ethanol extracts of $A$. adianthifolia (stem bark) used in Southern Africa to treat memory loss and Alzheimer's disease, have been screened for acetylcholinesterase inhibitory activity [13]. Kim et al. [14] reported that the aqueous extract of A. julibrissin had anxiolytic-like effects in rats as assessed using the elevated plus-maze test. Also, a recent study indicated that julibroside $\mathrm{C} 1$ extracted from A. julibrissin stem bark produced potent anxiolytic-like effects in mice [15]. Previously published data by our group demonstrated by HPLC analyses that among flavones, the main constituent of the aqueous extract of A. adianthifolia leaves is apigenin, responsible for the observed cognitive-enhancing effects in the 6-OHDAlesion rodent model of PD [16]. Moreover, it was claimed that saponins from Albizia lebbeck could be used in treatment of Alzheimer's and PD [17].

In this study we examined the effects of the aqueous extract of $A$. adianthifolia leaves on anxiety and depression levels, as well as the importance of the aqueous extract in oxidative stress status in the amygdala of 6-OHDAtreated rats. Correlation between the anxiety-depressionlike behaviors and the levels of the main oxidative stress markers from the amygdala of 6-OHDA-treated rats, as a result of the aqueous extract administration was also investigated.

\section{Methods}

Plant material and plant extract

Albizia adianthifolia leaves were collected in Elounden, near Yaoundé (Cameroon) in June 2010 and identified by Dr. Nolé Tsabang at the National Herbarium, Yaoundé where a voucher specimen ( $\left.\mathrm{N}^{\circ} \mathrm{HNC} 29997\right)$ was registered and deposited for ready reference. All locations where the plant was collected were not privately-owned or protected in any way and the field studies did not involve endangered or protected species. A. adianthifolia leaves were air dried and pulverized into fine powder. Five hundred grams of pulverized sample material was macerated in $5 \mathrm{~L}$ of distilled water for $48 \mathrm{~h}$ at room temperature and shaking regularly. Then the mixture was filtered through Whatman filter paper no. 3 . The aqueous extract was then lyophilized to obtain powder used for our various tests. The given powder yield was $4 \%(\mathrm{v} / \mathrm{w})$. The dried extract was dissolved in distilled water and administered by gastric gavage to animals at the doses of 150 and $300 \mathrm{mg} / \mathrm{kg}$ body weight.

\section{Animals}

60 male Wistar rats weighing $350 \pm 50 \mathrm{~g}$ at the start of the experiment were used. The animals were housed in a temperature and light-controlled room $\left(22{ }^{\circ} \mathrm{C}\right.$, a 12 -h cycle starting at 08:00 h) and were fed and allowed to drink water ad libitum. Rats were treated in accordance with the guidelines of animal bioethics from the Act on Animal Experimentation and Animal Health and Welfare from Romania and all procedures were in compliance with Directive 2010/63/EU of the European Parliament and of the Council of 22 September 2010 on the protection of animals used for scientific purposes. The protocol was approved by the Committee on the Ethics of Animal Experiments of the Alexandru Ioan Cuza University of Iasi, Romania (Permit Number: 1502723). All surgery was performed under sodium pentobarbital anesthesia, and all efforts were made to minimize animal suffering and to reduce the number of animal used. For the elevated plusmaze and forced swimming tests were employed the same group of rats.

\section{Drugs}

6-Hydroxydopamine (free base, 6-OHDA), desipramine, sodium pentobarbital, diazepam hydrochloride and tramadol (Sigma-Aldrich, Germany) were dissolved in 
an isotonic solution $(0.9 \% \mathrm{NaCl})$. All other reagents were purchased from Sigma-Aldrich, Germany.

\section{Neurosurgery}

All surgical procedures were conducted under aseptic conditions, under sodium pentobarbital $(50 \mathrm{mg} / \mathrm{kg}$ b.w., i.p.,) anesthesia. Rats were mounted in the stereotaxic apparatus with the nose oriented $11^{\circ}$ below horizontal zero plane. Thereafter, the animals received a right-unilaterally intranigral injections of $5 \mu \mathrm{L}$ of $0.9 \%$ saline containing $2.5 \mu \mathrm{g} / \mu \mathrm{L}$ 6-OHDA (free base) and $0.2 \%$ ascorbic acid $(\mathrm{w} / \mathrm{v})$ at a rate of $1 \mu \mathrm{L} / \mathrm{min}$ at the following coordinates: $5.5 \mathrm{~mm}$ posterior to bregma; $2.0 \mathrm{~mm}$ lateral to the midline; $7.4 \mathrm{~mm}$ ventral to the surface of the cortex, according to the rat brain atlas [18]. All rats sustaining 6OHDA lesion were pretreated with desipramine (25 mg/kg, i.p. in saline) $30 \mathrm{~min}$ before anesthesia in order to protect noradrenergic system. The rats in the control group (sham-operated) were given $5 \mu \mathrm{L}$ of $0.9 \%$ saline - $0.2 \%$ ascorbic acid administered in a similar manner as the solution containing 6OHDA.

\section{Postoperative care}

Recovery from anesthesia took approximately $6 \mathrm{~h}$. The rats were kept in well-ventilated room at $22{ }^{\circ} \mathrm{C}$ in individual cages till they gained full consciousness and were then housed together in a group of five animals per cage. Food was kept inside the cages during the first week so that animals could easily access it without any physical trauma due to surgical intervention.

\section{Drug administration}

The rats were divided into 6 groups (10 per group): (1) control group (sham-operated, received orally distilled water treatment); (2) Diazepam alone-treated group (sham-operated, DZP, $1.5 \mathrm{mg} / \mathrm{kg}$ ); (3) Tramadol alonetreated group (sham-operated, TRM, $10 \mathrm{mg} / \mathrm{kg}$ ); (4) 6OHDA-lesioned group, as negative control, received orally distilled water treatment; (5) 6-OHDA-lesioned group received orally $150 \mathrm{mg} / \mathrm{kg}$ of the aqueous extract of $A$. adianthifolia leaves treatment (6-OHDA + AE $(150 \mathrm{mg} / \mathrm{kg}))$ and (6) 6-OHDA-lesioned group received orally $300 \mathrm{mg} / \mathrm{kg}$ of the aqueous extract of $A$. adianthifolia leaves treatment (6-OHDA + AE $(300 \mathrm{mg} / \mathrm{kg})$ ). The administration of the distilled water and the aqueous extract was performed orally by gastric gavage with rat biomedical needles (length $7.62 \mathrm{~cm}$, ball diameter $4 \mathrm{~mm}$, straight). The volume administered was $10 \mathrm{~mL} / \mathrm{kg}$ of body weight, daily, for 21 consecutive days after neurosurgery. The aqueous extract doses $(150 \mathrm{mg} / \mathrm{kg}$ and $300 \mathrm{mg} / \mathrm{kg}$ ) used in this experiment were chosen since they have been demonstrated by our group to provide significant effects on memory formation and antioxidant profile [16]. Diazepam hydrochloride (Sigma-Aldrich, Germany) and tramadol (Sigma-Aldrich, Germany) were used as positive controls and were injected intraperitoneally (i.p.) in a volume of $1 \mathrm{~mL} / \mathrm{kg}$ in the sham-operated rats, $1 \mathrm{~h}$ before behaviorally tested.

\section{Rotational behavior}

The animals were tested for rotational behavior by pergolide $(0.5 \mathrm{mg} / \mathrm{kg}$, b.w., s.c., Sigma-Aldrich, Germany) 1 week after the 6-OHDA injection. The drug pergolide functions as a dopamine receptor agonist for $\mathrm{D}_{2}$ and $\mathrm{D}_{1}$ receptors and as a ligand to serotonin $5-\mathrm{HT}_{1 \mathrm{~A}}, 5-\mathrm{HT}_{1 \mathrm{~B}}$, $5-\mathrm{HT}_{2 \mathrm{~A}}, 5-\mathrm{HT}_{2 \mathrm{~B}}$, and $5-\mathrm{HT}_{2 \mathrm{C}}$ receptors [19]. Also, it was argued that pergolide induced contralateral rotation in animals with striatal lesion after systemic administration [20]. Briefly, 1 min after pergolide injection, full rotations were counted in a cylindrical container (a diameter of $33 \mathrm{~cm}$ and a height of $35 \mathrm{~cm}$ ) at $10 \mathrm{~min}$ intervals for $60 \mathrm{~min}$ in a quiet isolated room. Rotations in the ipsilateral and contralateral directions were counted separately and the analyses were based on the net scores (contralateral minus ipsilateral rotations) recorded for $60 \mathrm{~min}$ [21].

\section{Elevated plus-maze task}

Behavior in the elevated plus-maze (EPM) is largely used to assess exploration, anxiety and motor behavior. The EPM consists of four arms, $49 \mathrm{~cm}$ long and $10 \mathrm{~cm}$ wide, elevated $50 \mathrm{~cm}$ above the ground. Two arms were enclosed by walls $30 \mathrm{~cm}$ high and the other two arms were exposed. The illumination was set at $400 \mathrm{~lx}$. $30 \mathrm{~min}$ after the aqueous extract of $A$. adianthifolia leaves administration, each rat was placed in the center of the maze facing one closed arm. Behavior was observed for $5 \mathrm{~min}$, and the time spent and number of entries into the open and enclosed arms was counted [22]. The percentages of time spent in the open arms (time spent in the open arms/time spent in all arms $x$ 100) were calculated. In addition, the total number of openand enclosed-arm entries, which indicates the locomotors activity of animals [23], was measured. An entry was defined as an animal placing all four paws into an arm, and no time was recorded when the animal was in the central area. The maze was cleaned with $10 \%$ ethanol solution and dried with a cloth before the next animal was tested. Behavioral data were automatically tracked and recorded using ANY-maze behavioral software (Stoelting Co., USA, version 4.5).

\section{Forced swimming test (FST)}

The possible antidepressant effects of the aqueous extract of $A$. adianthifolia leaves were assessed, basically using the same method described by Campos et al. [24] 
but with modification. On the first day of the experiments (pretest session), rats were individually placed into cylindrical recipients (diameter $30 \mathrm{~cm}$, height $59 \mathrm{~cm}$ ) containing $25 \mathrm{~cm}$ of water at $26 \pm 1{ }^{\circ} \mathrm{C}$. The animals were left to swim for $15 \mathrm{~min}$ before being removed, dried and returned to their cages. The procedure was repeated $24 \mathrm{~h}$ later, in a 6 min swim session (test session), $30 \mathrm{~min}$ after the aqueous extract of $A$. adianthifolia leaves administration. During the test session, the following behavioral responses were recorded: (1) immobility (time spent floating with the minimal movements to keep the head above the water) and (2) swimming (time spent with active swimming movements).

\section{Biochemical parameter assay}

Three weeks after the administration of aqueous extract of $A$. adianthifolia leaves in 6-OHDA-lesioned animals groups, all rats were deeply anesthetized (using sodium pentobarbital, $100 \mathrm{mg} / \mathrm{kg}$ b.w., i.p., Sigma-Aldrich, Germany) and decapitated and whole brains were removed. Bilateral amygdala was carefully excised. Each of the amygdala samples were weighted and homogenized (1:10) with Potter Homogenizer coupled with Cole-Parmer Servodyne Mixer in ice-cold 0.1 M potassium phosphate buffer ( $\mathrm{pH} 7.4), 1.15 \% \mathrm{KCl}$. The homogenate was centrifuged $(15 \mathrm{~min}$ at $960 \mathrm{x} \mathrm{g}$ ) and the supernatant was used for assays of SOD, GPX, CAT specific activities, total content of reduced GSH, protein carbonyl and MDA levels.

\section{Determination of SOD activity}

The activity of superoxide dismutase (SOD, EC 1.15.1.1) was assayed by monitoring its ability to inhibit the photochemical reduction of nitroblue tetrazolium (NBT). Each $1.5 \mathrm{~mL}$ reaction mixture contained $100 \mathrm{mM}$ TRIS/HCl (pH 7.8), $75 \mathrm{mM} \mathrm{NBT}, 2 \mu \mathrm{M}$ riboflavin, $6 \mathrm{mM}$ EDTA, and $200 \mu \mathrm{L}$ of supernatant. Monitoring the increase in absorbance at $560 \mathrm{~nm}$ followed the production of blue formazan. One unit of SOD is defined as the quantity required to inhibit the rate of NBT reduction by $50 \%$ as previously described by Winterbourn et al. [25]. The enzyme activity is expressed as units/mg protein.

\section{Determination of GPX activity}

Glutathione peroxidase (GPX, E.C. 1.11.1.9) activity was analyzed by a spectrophotometric assay. A reaction mixture consisting of $1 \mathrm{~mL}$ of $0.4 \mathrm{M}$ phosphate buffer $(\mathrm{pH} 7.0)$ containing $0.4 \mathrm{mM}$ EDTA, $1 \mathrm{~mL}$ of $5 \mathrm{mM}$ $\mathrm{NaN}_{3}, 1 \mathrm{~mL}$ of $4 \mathrm{mM}$ glutathione (GSH), and $200 \mu \mathrm{L}$ of supernatant was pre-incubated at $37^{\circ} \mathrm{C}$ for $5 \mathrm{~min}$. Then $1 \mathrm{~mL}$ of $4 \mathrm{mM} \mathrm{H}_{2} \mathrm{O}_{2}$ was added and incubated at $37{ }^{\circ} \mathrm{C}$ for further $5 \mathrm{~min}$. The excess amount of GSH was quantified by the DTNB method as previously described by Sharma and Gupta [26]. One unit of GPX is defined as the amount of enzyme required to oxidize $1 \mathrm{nmol} \mathrm{GSH} /$ min. The enzyme activity is expressed as units/mg protein.

\section{Determination of CAT activity}

Catalase (CAT, EC 1.11.1.6) activity was assayed following the method of Sinha [27]. The reaction mixture consisted of $150 \mu \mathrm{L}$ phosphate buffer (0.01 M, pH 7.0), $100 \mu \mathrm{L}$ supernatant. Reaction was started by adding $250 \mu \mathrm{L} \mathrm{H}_{2} \mathrm{O}_{2} 0.16 \mathrm{M}$, incubated at $37{ }^{\circ} \mathrm{C}$ for $1 \mathrm{~min}$ and reaction was stopped by addition of $1.0 \mathrm{~mL}$ of dichromate: acetic acid reagent. The tubes were immediately kept in a boiling water bath for $15 \mathrm{~min}$ and the green colour developed during the reaction was read at $570 \mathrm{~nm}$ on a spectrophotometer. Control tubes, devoid of enzyme, were also processed in parallel. The enzyme activity is expressed as $\mu \mathrm{mol}$ of $\mathrm{H}_{2} \mathrm{O}_{2}$ consumed $/ \mathrm{min} / \mathrm{mg}$ protein.

\section{Total content of reduced GSH}

Glutathione (GSH) was measured following the method of Fukuzawa and Tokumura [28]. $200 \mu \mathrm{L}$ of supernatant was added to $1.1 \mathrm{~mL}$ of $0.25 \mathrm{M}$ sodium phosphate buffer ( $\mathrm{pH}$ 7.4) followed by the addition of $130 \mu \mathrm{L}$ DTNB $0.04 \%$. Finally, the mixture was brought to a final volume of $1.5 \mathrm{~mL}$ with distilled water and absorbance was read in a spectrophotometer at $412 \mathrm{~nm}$ and results were expressed as $\mu \mathrm{g} \mathrm{GSH} / \mu \mathrm{g}$ protein.

\section{Determination of protein carbonyl level}

The extent of protein oxidation in the amygdala was assessed by measuring the content of protein carbonyl groups, using 2,4- dinitrophenylhydrazine (DNPH) derivatization as described by Oliver et al. [29] and following the indications of Luo and Wehr [30]. Basically, the supernatant fraction was divided into two equal aliquots containing approximately $2 \mathrm{mg}$ of protein each. Both aliquots were precipitated with $10 \%$ trichloroacetic acid (TCA, w/v, final concentration). One sample was treated with $2 \mathrm{~N} \mathrm{HCl}$, and the other sample was treated with an equal volume of $0.2 \%(\mathrm{w} / \mathrm{v}) \mathrm{DNPH}$ in $2 \mathrm{~N} \mathrm{HCI}$. Both samples were incubated at $25{ }^{\circ} \mathrm{C}$ and stirred at $5 \mathrm{~min}$ intervals. The samples were then reprecipitated with $10 \%$ TCA (final concentration) and subsequently extracted with ethanol-ethyl acetate $(1: 1, \mathrm{v} / \mathrm{v})$ and then reprecipitated at $10 \%$ TCA. The pellets were carefully drained and dissolved in $6 \mathrm{M}$ guanidine hydrochloride with $20 \mathrm{mM}$ sodium phosphate buffer, $\mathrm{pH}$ 6.5. Insoluble debris was removed by centrifugation at $13000 \mathrm{xg}$ at $4{ }^{\circ} \mathrm{C}$. The absorbance at $370 \mathrm{~nm}$ of the DNPH-treated sample versus the $\mathrm{HCl}$ control was recorded, and the results are expressed as nmols of DNPH incorporated $/ \mathrm{mg}$ of protein based on an average absorptivity of $21.0 \mathrm{mM}^{-1} \mathrm{~cm}^{-1}$ for most aliphatic hydrazones. 


\section{Determination of MDA level}

Malondialdehyde (MDA), which is an indicator of lipid peroxidation, was spectrophotometrically measured by using the thiobarbituric acid assay [31]. $200 \mu \mathrm{L}$ of supernatant was added and briefly mixed with $1 \mathrm{~mL}$ of $50 \%$ trichloroacetic acid in $0.1 \mathrm{M} \mathrm{HCl}$ and $1 \mathrm{~mL}$ of $26 \mathrm{mM}$ thiobarbituric acid. After vortex mixing, samples were maintained at $95{ }^{\circ} \mathrm{C}$ for $20 \mathrm{~min}$. Afterwards, samples were centrifuged at $960 \times \mathrm{g}$ for $10 \mathrm{~min}$ and supernatants were read at $532 \mathrm{~nm}$. A calibration curve was constructed using MDA as standard and the results were expressed as $\mathrm{nmol} / \mathrm{mg}$ protein.

\section{Estimation of protein concentration}

Estimation of protein was done using a bicinchoninic acid (BCA) protein assay kit (Sigma-Aldrich, Germany). The BCA protein assay is a detergent-compatible formulation based on BCA for the colorimetric detection and quantification of total protein, as previously described by Smith et al. [32].

\section{DNA fragmentation}

Total DNA was isolated from the amygdala samples using the phenol/chloroform method as previously described by Ausubel et al. [33]. $50 \mathrm{mg}$ tissue sample was digested overnight at $37{ }^{\circ} \mathrm{C}$ in $0.6 \mathrm{~mL}$ digestion buffer (100 mM NaCl, $10 \mathrm{mM}$ TRIS/HCl, $25 \mathrm{mM}$ EDTA $\mathrm{pH} 8.00,0.5 \%$ SDS) containing $0.1 \mathrm{mg} / \mathrm{mL}$ proteinase $\mathrm{K}$ (Boehringer Mannheim, Germany). The digest was extracted with equal volumes of TRIS-saturated phenol (pH 8.0) (Roti-phenol, Roth, Germany) by shaking gently to completely mix the two phases. The phases were then separated by centrifugation and the aqueous phase (approx. $0.6 \mathrm{ml}$ ) was transferred to another tube avoiding interphase. The DNA was then precipitated by adding $300 \mu \mathrm{L}$ of $7.5 \mathrm{M}$ ammonium acetate (i.e., $1 / 2$ of volume) and equal volume of $100 \%$ ethanol at room temperature and shaken gently to mix thoroughly. DNA seen as stringy precipitate was pelleted by centrifugation and washed with $70 \%$ ethanol to remove traces of sodium dodecyl sulfate and phenol. After removing ethanol, DNA was air-dried for $10 \mathrm{~min}$ at room temperature and suspended with $50 \mu \mathrm{L}$ of $10 \mathrm{mM}$ TRIS (pH 8.0), 1 mM EDTA. DNA content was determined spectrophotometrically by absorbance at $260 \mathrm{~nm}$ and the purity of the DNA was confirmed by a ratio $>1.8$ at $260 / 280 \mathrm{~nm}$. Approximately $0.5 \mathrm{mg}$ genomic DNA was dissolved in a mixture of $10 \mu \mathrm{L}$ of TRIS-EDTA and $5 \mu \mathrm{L}$ of gel loading buffer $(0.25 \%$ bromophenol blue, $0.25 \%$ xylene cyanol FF, $30 \%(\mathrm{v} / \mathrm{v})$ glycerol) and then loaded on a $1.5 \%$ agarose gel in TRIS-boric acid-EDTA (TBE) buffer (89 mM Tris boric acid, $2 \mathrm{mM}$ EDTA, $\mathrm{pH}$ 8.0). Electrophoresis was performed in TBE at $120 \mathrm{~V}$ until sufficient resolution was obtained. A 1-kb
DNA ladder (New England Biolabs, Ipswich, MA) was used as a standard size marker. The bands were visualized by ethidium bromide staining under UV light.

\section{6-OHDA-lesion control}

Pergolide-induced rotational behavior test was employed to validate unilateral damage to dopamine nigrostriatal neurons. The pergolide results confirm the impairment of the dopaminergic system as previously described [16].

\section{Statistical analysis}

Behavioral scores within elevated plus-maze and forced swimming tests and biochemical data were analyzed by one-way analysis of variance (ANOVA) using XLSTAT version 2012. 1.01 software, Addinsoft. All results are expressed as mean \pm S.E.M. $F$ values for which $p<0.05$ were regarded as statistically significant. Significant differences were determined by Tukey's post hoc test. Pearson's correlation coefficient and regression analysis were used in order to evaluate the connection between behavioral measures, the antioxidant defence and lipid peroxidation.

\section{Results}

\section{Effect pergolide on rotational behavior}

Pergolide-induced rotational behavior was analyzed to assess the unilateral degeneration of the dopamine nigrostriatal neurons. Control group did not show any significant bias in turning behavior after receiving pergolide injection. In contrast, rats exhibited contralateral rotational behavior following pergolide challenge in 1 week after the unilateral administration of 6-OHDA into the $\mathrm{SN}$. In the rotational behavioral test, ANOVA revealed an attenuation of asymmetric motor behavior $(\mathrm{F}(3,36)=20.03, \quad p<0.0001)$ in experimental animals treated with the aqueous extract of $A$. adianthifolia leaves (150 and $300 \mathrm{mg} / \mathrm{kg}$ ) as compared to control group (Fig. 1). Additionally, Tukey's post hoc analysis revealed a significant difference between the control and 6-OHDA groups $(p<0.0001)$, control and 6-OHDA $+\mathrm{AE}$ $(150 \mathrm{mg} / \mathrm{kg})$ groups $(p<0.0001)$, control and 6-OHDA $+\mathrm{AE}(300 \mathrm{mg} / \mathrm{kg})$ groups $(p<0.0001), 6$-OHDA and 6OHDA + AE $(150 \mathrm{mg} / \mathrm{kg})$ groups $(p<0.001), 6-\mathrm{OHDA}$ and $6-\mathrm{OHDA}+\mathrm{AE}(300 \mathrm{mg} / \mathrm{kg})$ groups $(p<0.0001)$ and $6-\mathrm{OHDA}+\mathrm{AE}(150 \mathrm{mg} / \mathrm{kg})$ and $6-\mathrm{OHDA}+\mathrm{AE}$ $(300 \mathrm{mg} / \mathrm{kg})$ groups $(p<0.0001)$ (Fig. 1).

\section{Effect of Albizia adianthifolia extract on elevated plus- maze behavior}

As can be seen in Fig. 2a, in the elevated plus-maze ANOVA revealed a significant increase of the percentage of the time spent in the open arms in 6-OHDA-lesioned groups treated with low-and high-doses (150 and $300 \mathrm{mg} / \mathrm{kg}$ ) of the aqueous extract of $A$. adianthifolia 


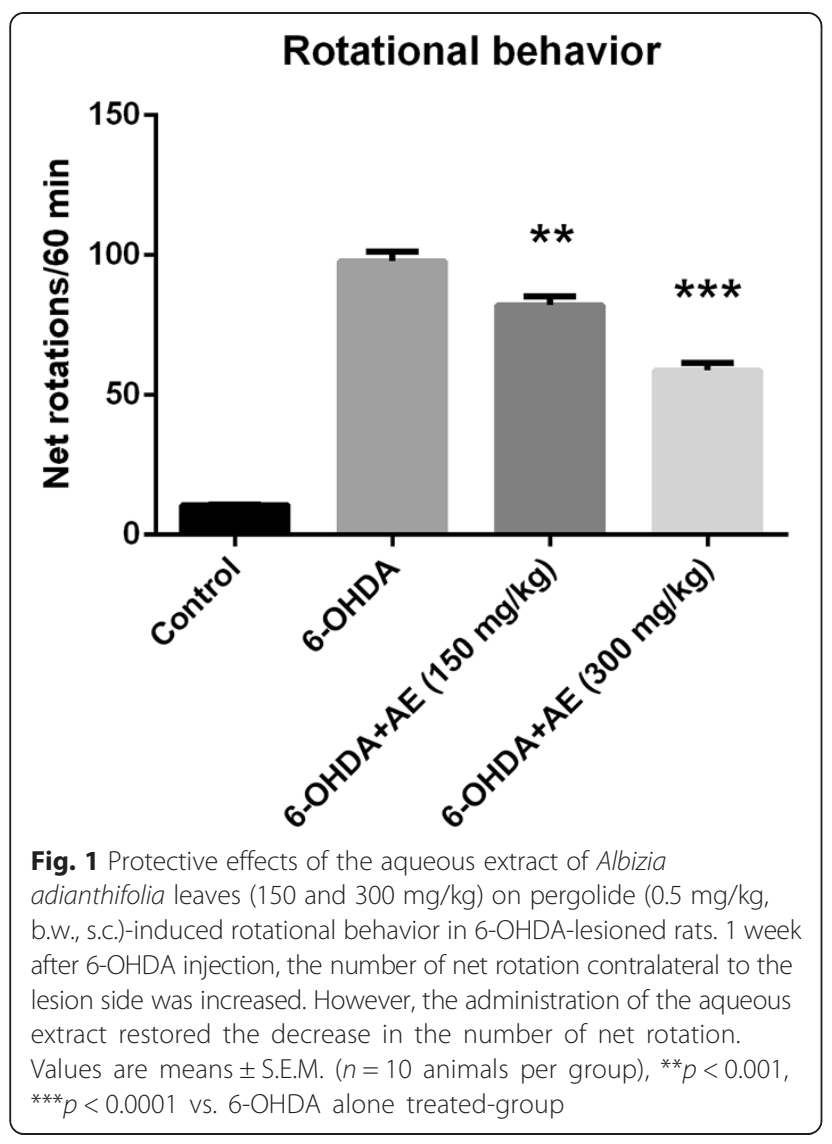

leaves $(\mathrm{F}(3,36)=3.51, p<0.05)$, suggesting significant anxiolytic effects. Additionally, Tukey's post hoc analysis revealed a significant difference between the control and 6-OHDA groups $(p<0.05)$, control and 6-OHDA $+\mathrm{AE}(150 \mathrm{mg} / \mathrm{kg})$ groups $(p<0.05)$, control and 6-OHDA $+\mathrm{AE}(300 \mathrm{mg} / \mathrm{kg})$ groups $(p<0.01)$, DIAZ and 6 -OHDA groups $(p<0.05)$, DIAZ and 6-OHDA + AE $(150 \mathrm{mg} / \mathrm{kg})$ groups $(p<0.001)$, DIAZ and 6-OHDA + AE $(300 \mathrm{mg} / \mathrm{kg}) \quad(p<0.001), 6-$ OHDA and 6-OHDA + AE $(150 \mathrm{mg} / \mathrm{kg})$ groups $(p<0.01)$ and 6-OHDA and 6-OHDA + AE $(300 \mathrm{mg} / \mathrm{kg})$ groups $(p<0.01)$ (Fig. 2a) for the percentage of the time spent in the open arms, indicating that the aqueous extract of A. adianthifolia leaves has anxiolytic-like profile. Nonsignificant differences between control and DIAZ were observed $(p>0.05)$.

As can be seen in Fig. 2b, in the elevated plusmaze ANOVA revealed a significant increase of the number of open-arm entries in 6-OHDA-lesioned groups treated with low-and high-doses (150 and $300 \mathrm{mg} / \mathrm{kg}$ ) of the aqueous extract of $A$. adianthifolia leaves $(F(3,36)=8.03, p<0.001)$, suggesting significant anxiolytic effects. Additionally, Tukey's post hoc analysis revealed a significant difference between the control and 6-OHDA groups $(p<0.001)$, control and 6-OHDA $+\operatorname{AE}(150 \mathrm{mg} / \mathrm{kg})$ groups $(p<0.05)$, control and 6$\mathrm{OHDA}+\mathrm{AE}(300 \mathrm{mg} / \mathrm{kg})$ groups $(p<0.01)$, DIAZ and
6-OHDA groups $(p<0.05), 6-$ OHDA and 6-OHDA + $\mathrm{AE}(150 \mathrm{mg} / \mathrm{kg})$ groups $(p<0.0001)$ and 6-OHDA and 6 -OHDA + AE $(300 \mathrm{mg} / \mathrm{kg})$ groups $(p<0.001)$ (Fig. $2 \mathrm{~b})$ for the number of open-arm entries, indicating that the aqueous extract of $A$. adianthifolia leaves has anxiolyticlike profile as suggested above. Non-significant differences between control and DIAZ were observed $(p>0.05)$.

As can be seen in Fig. 2c, in the elevated plus-maze ANOVA revealed a significant increase on the exploratory locomotor activity in 6-OHDA-lesioned groups treated with low-and high-doses (150 and $300 \mathrm{mg} / \mathrm{kg}$ ) of the aqueous extract of $A$. adianthifolia leaves $(\mathrm{F}(3,36)=48.87, p<0.0001)$, as evidenced by the number of crossing. Additionally, Tukey's post hoc analysis revealed a significant difference between the control and DIAZ groups $(p<0.0001)$, control and 6-OHDA groups $(p<0.05)$, control and 6-OHDA + AE $(150 \mathrm{mg} / \mathrm{kg})$ groups $(p<0.01)$, control and 6-OHDA $+\mathrm{AE}(300 \mathrm{mg} / \mathrm{kg})$ groups $(p<0.01)$, DIAZ and 6-OHDA groups $(p<0.0001)$, DIAZ and $6-\mathrm{OHDA}+\mathrm{AE}(150 \mathrm{mg} / \mathrm{kg})$ groups $(p<0.0001)$, DIAZ and 6-OHDA + AE $(300 \mathrm{mg} / \mathrm{kg})$ groups $(p<$ $0.0001), 6-\mathrm{OHDA}$ and 6-OHDA + AE $(150 \mathrm{mg} / \mathrm{kg})$ groups $(p<0.01)$ and 6-OHDA and 6-OHDA + AE $(300 \mathrm{mg} / \mathrm{kg})$ groups $(p<0.01)$ (Fig. 2c) for the number of crossing. Also, significant differences between control and DIAZ were observed $(p<0.0001)$.

\section{Effect of Albizia adianthifolia extract in the rat forced swimming test}

In the forced swimming test, ANOVA revealed a significant effect on depressive-like response in 6OHDA-lesioned groups treated with low-and high-doses (150 and $300 \mathrm{mg} / \mathrm{kg}$ ) of the aqueous extract of $A$. adianthifolia leaves, as evidenced by the swimming time $(\mathrm{F}(3,36)=21.09, p<0.0001)$ (Fig. 3a) and the immobility time $(\mathrm{F}(3,36)=78.59, p<0.0001)$ (Fig. 3b). Additionally, Tukey's post hoc analysis revealed significant differences between the control and TRM groups $(p<0.0001)$, control and 6-OHDA groups $(p<0.0001)$, control and 6$\mathrm{OHDA}+\mathrm{AE}(150 \mathrm{mg} / \mathrm{kg})$ groups $(p<0.0001)$, control and $6-\mathrm{OHDA}+\mathrm{AE}(300 \mathrm{mg} / \mathrm{kg})$ groups $(p<0.0001)$, TRM and 6-OHDA groups $(p<0.05), 6-O H D A$ and 6$\mathrm{OHDA}+\mathrm{AE}(150 \mathrm{mg} / \mathrm{kg})$ groups $(p<0.01), 6$-OHDA and 6-OHDA + AE $(300 \mathrm{mg} / \mathrm{kg})$ groups $(p<0.01)$ and $6-$ $\mathrm{OHDA}+\mathrm{AE}(150 \mathrm{mg} / \mathrm{kg})$ and 6-OHDA + AE (300 mg/ $\mathrm{kg})$ groups $(p<0.01)$ for the swimming time (Fig. 3a).

Moreover, Tukey's post hoc analysis revealed significant differences between the control and TRM groups $(p<0.01)$, control and 6-OHDA groups $(p<0.0001)$, TRM and 6OHDA groups $(p<0.0001), 6-\mathrm{OHDA}$ and $6-\mathrm{OHDA}+\mathrm{AE}$ $(150 \mathrm{mg} / \mathrm{kg})$ groups $(p<0.0001)$ and 6-OHDA and 6$\mathrm{OHDA}+\mathrm{AE}(300 \mathrm{mg} / \mathrm{kg})$ groups $(p<0.0001)$ for the immobility time (Fig. 3b). 
(a)

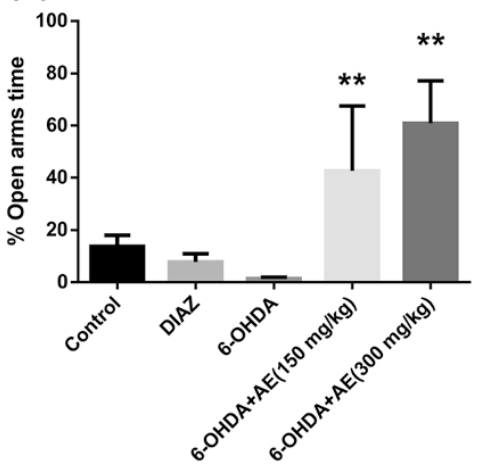

(b)

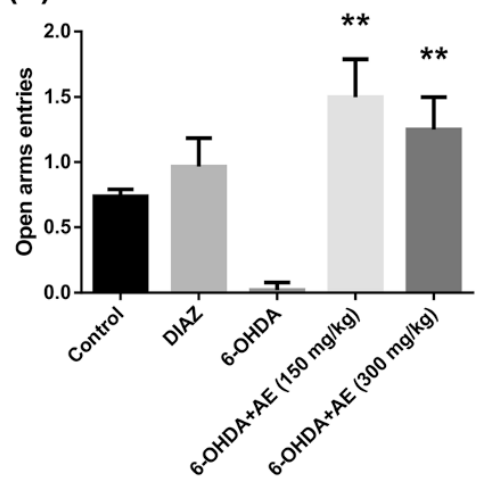

(c)

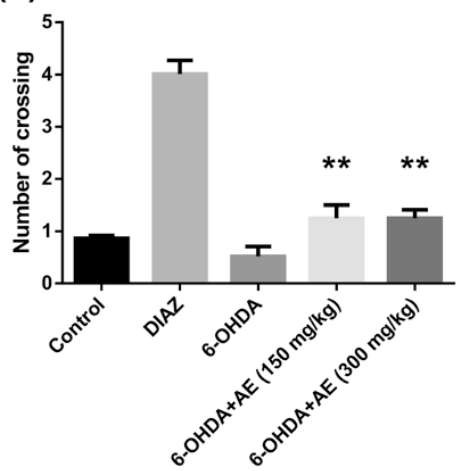

Fig. 2 Effects of the aqueous extract of Albizia adianthifolia leaves (150 and $300 \mathrm{mg} / \mathrm{kg}$ ) in the elevated plus-maze test on a the percentage of the time spent in the open arms, $\mathbf{b}$ the number of open-arm entries and $\mathbf{c}$ the number of crossing in the 6-OHDA-treated rats. Values are means \pm S.E.M. ( $n=10$ animals per group), ${ }^{* *} p<0.01$, vs. 6-OHDA alone treated-group

\section{Effect of Albizia adianthifolia extract on SOD, GPX and CAT activities}

For SOD specific activity estimated in the rat amygdala homogenates, ANOVA revealed a significant overall effect $(\mathrm{F}(3,36)=42.68, p<0.0001)$ (Fig. 4a).
Additionally, Tukey's post hoc analysis revealed significant differences between the control and 6-OHDA groups $(p<0.01)$, control and 6-OHDA + AE $(150 \mathrm{mg} /$ $\mathrm{kg})$ groups $(p<0.0001)$, control and 6-OHDA + AE $(300 \mathrm{mg} / \mathrm{kg})$ groups $(p<0.01), 6$-OHDA and 6-OHDA (a)

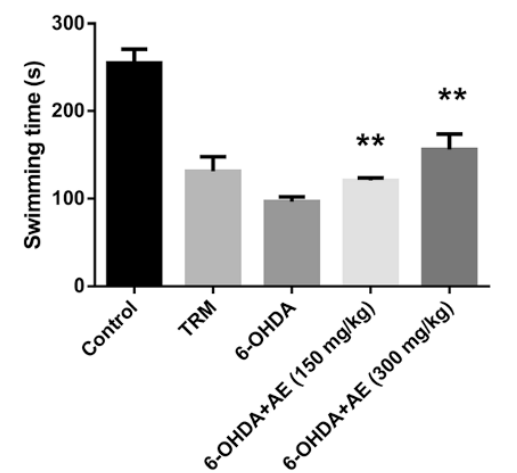

(b)

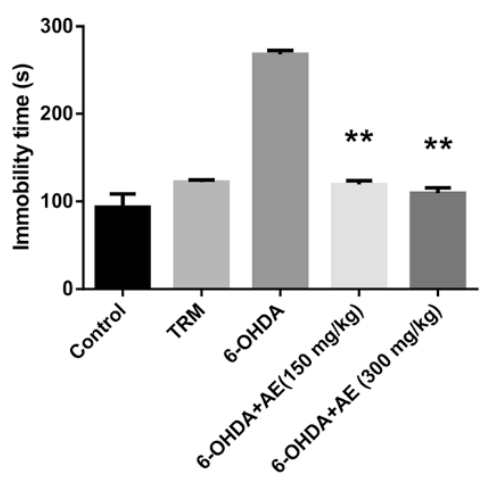

Fig. 3 Effects of the aqueous extract of Albizia adianthifolia leaves (150 and $300 \mathrm{mg} / \mathrm{kg}$ ) on $\mathbf{a}$ swimming time and $\mathbf{b}$ immobility time in the 6-OHDA-treated rats during the $6 \mathrm{~min}$ period in the forced swimming test. Values are means \pm S.E.M. ( $n=10$ animals per group), ${ }^{* *} p<0.01$ vs. 6-OHDA alone treated-group 
(a)

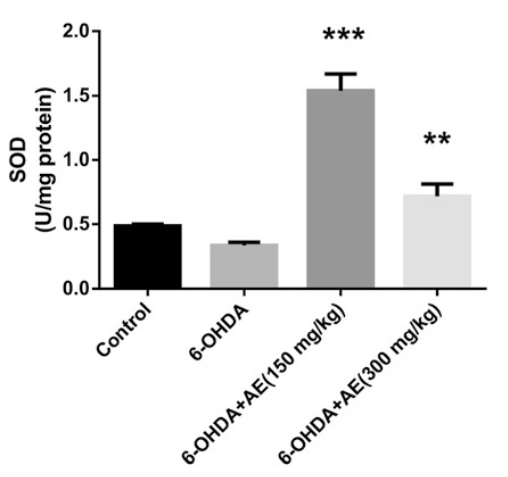

(c)

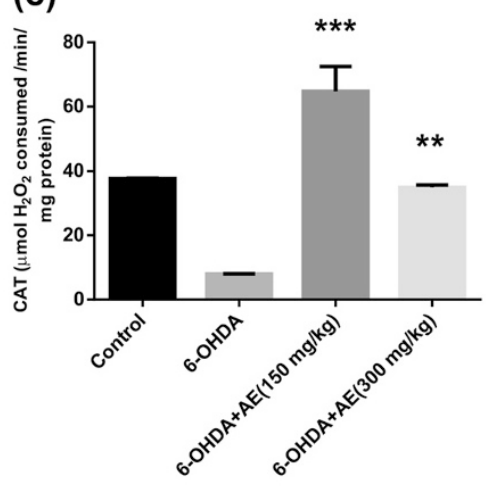

(e)

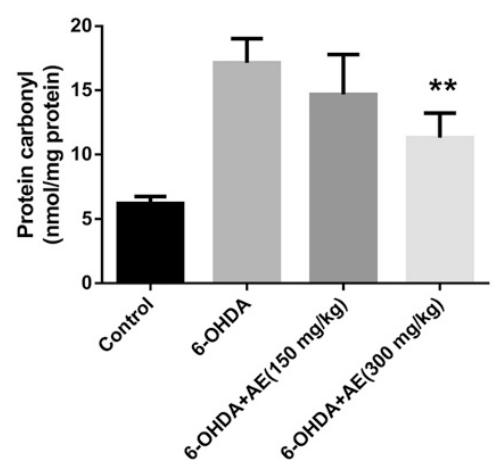

(b)

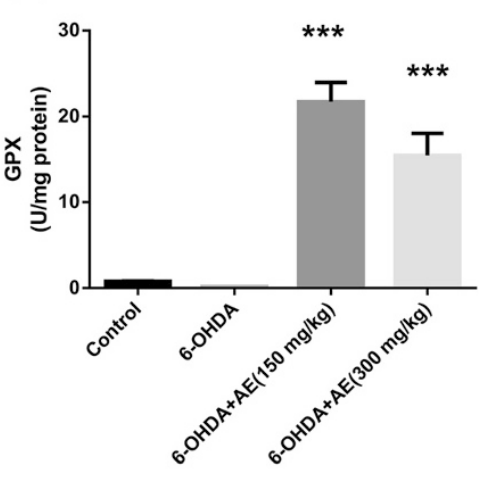

(d)

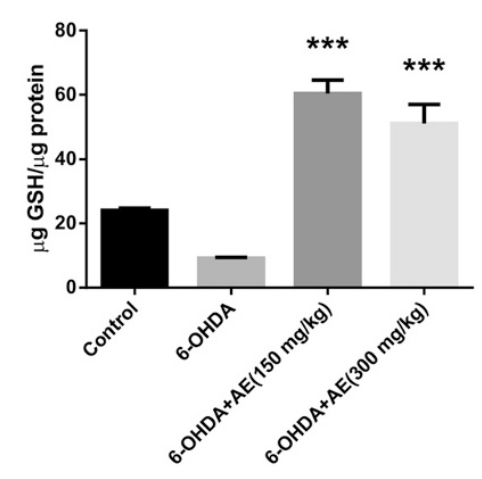

(f)

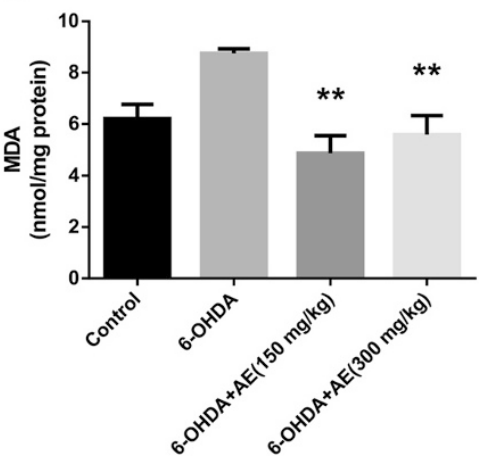

Fig. 4 Effects of the aqueous extract of Albizia adianthifolia leaves (150 and $300 \mathrm{mg} / \mathrm{kg}$ ) on a SOD, b GPX and c CAT specific activities, on d total content of reduced GSH, e protein carbonyl and $\mathbf{f}$ MDA levels in the 6-OHDA-treated rats. Values are means \pm S.E.M. ( $n=10$ animals per group), ${ }^{* *} p<0.001,{ }^{* *} p<0.0001$ vs. 6-OHDA alone treated-group

$+\mathrm{AE}(150 \mathrm{mg} / \mathrm{kg})$ groups $(p<0.0001), 6-O H D A$ and $6-\mathrm{OHDA}+\mathrm{AE}(300 \mathrm{mg} / \mathrm{kg})$ groups $(p<0.001)$ and $6-$ $\mathrm{OHDA}+\mathrm{AE}(150 \mathrm{mg} / \mathrm{kg})$ and 6-OHDA + AE (300 mg/ $\mathrm{kg})$ groups $(p<0.0001)$ for SOD specific activity.

For GPX specific activity estimated in the rat amygdala homogenates, ANOVA revealed a significant overall effect $(\mathrm{F}(3,36)=40.20, p<0.0001)$ (Fig. 4b). Additionally, Tukey's post hoc analysis revealed significant differences between the control and 6-OHDA + AE (150 mg/kg) groups $(p<0.0001)$, control and 6-
$\mathrm{OHDA}+\mathrm{AE}(300 \mathrm{mg} / \mathrm{kg})$ groups $(p<0.001), 6-\mathrm{OHDA}$ and $6-\mathrm{OHDA}+\mathrm{AE}(150 \mathrm{mg} / \mathrm{kg})$ groups $(p<0.0001)$ and 6-OHDA and 6-OHDA + AE $(300 \mathrm{mg} / \mathrm{kg})$ groups $(p<0.001)$ for GPX specific activity.

For CAT specific activity estimated in the rat amygdala homogenates, ANOVA revealed a significant overall effect $(\mathrm{F}(3,36)=35.40, p<0.0001)$ (Fig. 4c). Additionally, Tukey's post hoc analysis revealed significant differences between the control and 6OHDA groups $(p<0.001)$, control and 6-OHDA + AE 
$(150 \mathrm{mg} / \mathrm{kg})$ groups $(p<0.001), 6-\mathrm{OHDA}$ and 6-OHDA + $\mathrm{AE}(150 \mathrm{mg} / \mathrm{kg})$ groups $(p<0.0001), 6-\mathrm{OHDA}$ and 6 $\mathrm{OHDA}+\mathrm{AE}(300 \mathrm{mg} / \mathrm{kg})$ groups $(p<0.001)$ and $6-\mathrm{OHDA}$ $+\mathrm{AE}(150 \mathrm{mg} / \mathrm{kg})$ and $6-\mathrm{OHDA}+\mathrm{AE}(300 \mathrm{mg} / \mathrm{kg})$ groups $(p<0.001)$ for CAT specific activity.

\section{Effect of Albizia adianthifolia extract on total content of reduced GSH, protein carbonyl and MDA levels}

For the total content of reduced GSH estimated in the rat amygdala homogenates, ANOVA revealed a significant overall effect $(F(3,36)=41.79, p<0.0001)$ (Fig. 4d). Additionally, Tukey's post hoc analysis revealed significant differences between the control and 6-OHDA groups $(p<0.01)$, control and 6-OHDA $+\mathrm{AE}$ $(150 \mathrm{mg} / \mathrm{kg})$ groups $(p<0.0001)$, control and 6OHDA + AE $(300 \mathrm{mg} / \mathrm{kg})$ groups $(p<0.001), 6-$ OHDA and $6-\mathrm{OHDA}+\mathrm{AE}(150 \mathrm{mg} / \mathrm{kg})$ groups $(p<0.0001)$ and 6-OHDA vs. 6-OHDA + AE $(300 \mathrm{mg} / \mathrm{kg})$ groups $(p<0.0001)$ for the total content of reduced GSH.

For the protein carbonyl level ANOVA revealed a significant overall effect $(\mathrm{F}(3,36)=5.19, p<0.01)$ (Fig. 4e). Additionally, Tukey's post hoc analysis revealed significant differences between the control and 6-OHDA groups $(p<0.01)$, control and 6-OHDA + AE $(150 \mathrm{mg} /$ $\mathrm{kg})$ groups $(p<0.01)$, control and 6-OHDA + AE $(300 \mathrm{mg} / \mathrm{kg})$ groups $(p<0.01)$ and 6-OHDA and 6OHDA + AE $(300 \mathrm{mg} / \mathrm{kg})$ groups $(p<0.001)$ for protein carbonyl level.

For the MDA level ANOVA revealed a significant overall effect $(F(3,36)=8.48, p<0.001)$ (Fig. 4f). Additionally, Tukey's post hoc analysis revealed significant differences between the control and 6-OHDA groups $(p<0.001), 6-\mathrm{OHDA}$ and 6-OHDA + AE $(150 \mathrm{mg} / \mathrm{kg})$ groups $(p<0.001)$ and 6-OHDA and 6-OHDA $+\mathrm{AE}$ (300 mg/kg) groups $(p<0.01)$ for MDA level.

These results support the hypothesis that the aqueous extract of $A$. adianthifolia leaves may have induced a decrease in neuronal oxidative stress.

More importantly, when linear regression was determined, significant correlations between the number of entries in the open arms vs. MDA $(n=40, r=-0.791$, $p<0.001$ ) (Fig. 5a), the number of crossing vs. MDA ( $n=40, r=-0.872, p<0.001$ ) (Fig. 5b) were evidenced. Additionally, a significant correlation was evidenced by determination of the linear regression between SOD vs. MDA ( $n=40, r=-0.632, p<0.01)$ (Fig. 5c), GPX vs. MDA $(n=40, r=-0.675, p<0.01)$ (Fig. $5 \mathrm{~d}$ ), CAT vs. MDA ( $n=40, r=-0.855, p<0.0001)$ (Fig. 5e) and GSH vs. MDA $(n=40, r=-0.771, p<0.0001)$ (Fig. 5f).

These data suggest that anxiolytic responses within elevated plus-maze a and increase of the antioxidant defence along with decrease of lipid peroxidation could related with the involvement of the aqueous extract of
A. adianthifolia leaves in neuroprotection against 6OHDA-induced neuronal oxidative stress generation.

\section{Effect of Albizia adianthifolia extract on DNA fragmentation}

In our study, DNA cleavage patterns were absent in the aqueous extract groups as compared to 6-OHDA alonetreated group (Fig. 6), suggesting that the aqueous extract of $A$. adianthifolia leaves do not induce neurotoxicity and this effect could be related to its antioxidant activity.

\section{Discussion}

The present study was aimed to examine the anxiety-like behavior and depressive-like response following administration of the aqueous extract of $A$. adianthifolia leaves in rats subjected to intranigral injection of 6-OHDA. It has been reported that 6-OHDA-induce lesion of the striatum causes depression- and anxiety-like behavior [34].

Previously, we have reported apigenin as the main component of the aqueous extract of A. adianthifolia leaves [16]. Several studies indicated anxiolytic and antidepressant activity of apigenin in rats exposed to behavioral tests [35]. Moreover, it is reported that apigenin modulates the $\gamma$-aminobutyric acid (GABA)ergic system to produce the biological effect .

PD is accompanied by non-motor symptoms, including olfactory loss, cognitive decline, depression and anxiety, which frequently appear in the early stages or even during the premotor phase of the disease [34]. Psychiatric symptoms have been related to monoaminergic deficits within components of the limbic system implicated in emotional and affective functions. In fact, the progressive death of midbrain dopaminergic neurons in PD is paralleled by the concomitant degeneration of noradrenergic and serotonergic systems [36].

The 6-OHDA lesion used in this study affects both dopamine and noradrenaline innervation [34]. Therefore, to assess the contribution of these systems to anxiety and depression conditions, we limited the lesion with 6-OHDA to the dopamine neurons by pre-treating the rats with the selective noradrenaline reuptake inhibitor, desipramine. In addition, the pergolide results confirm the impairment of the dopaminergic system.

Our data show that intranigral unilateral injection of 6-OHDA significantly decreased the percentage of the time spent in the open arms and the number of open-arm entries in the elevated plus maze test, two indicative parameters of anxiety. This indicates that the 6-OHDA-treated rats experienced high levels of anxiety and were suitable for evaluating the presumed anxiolytic substances. Notably, we found that administration of the aqueous extract $(150 \mathrm{mg} / \mathrm{kg}$ and $300 \mathrm{mg} / \mathrm{kg}$ ) counteracts anxiety of rats produced by the 6-OHDA lesion, suggesting potent anxiolytic 

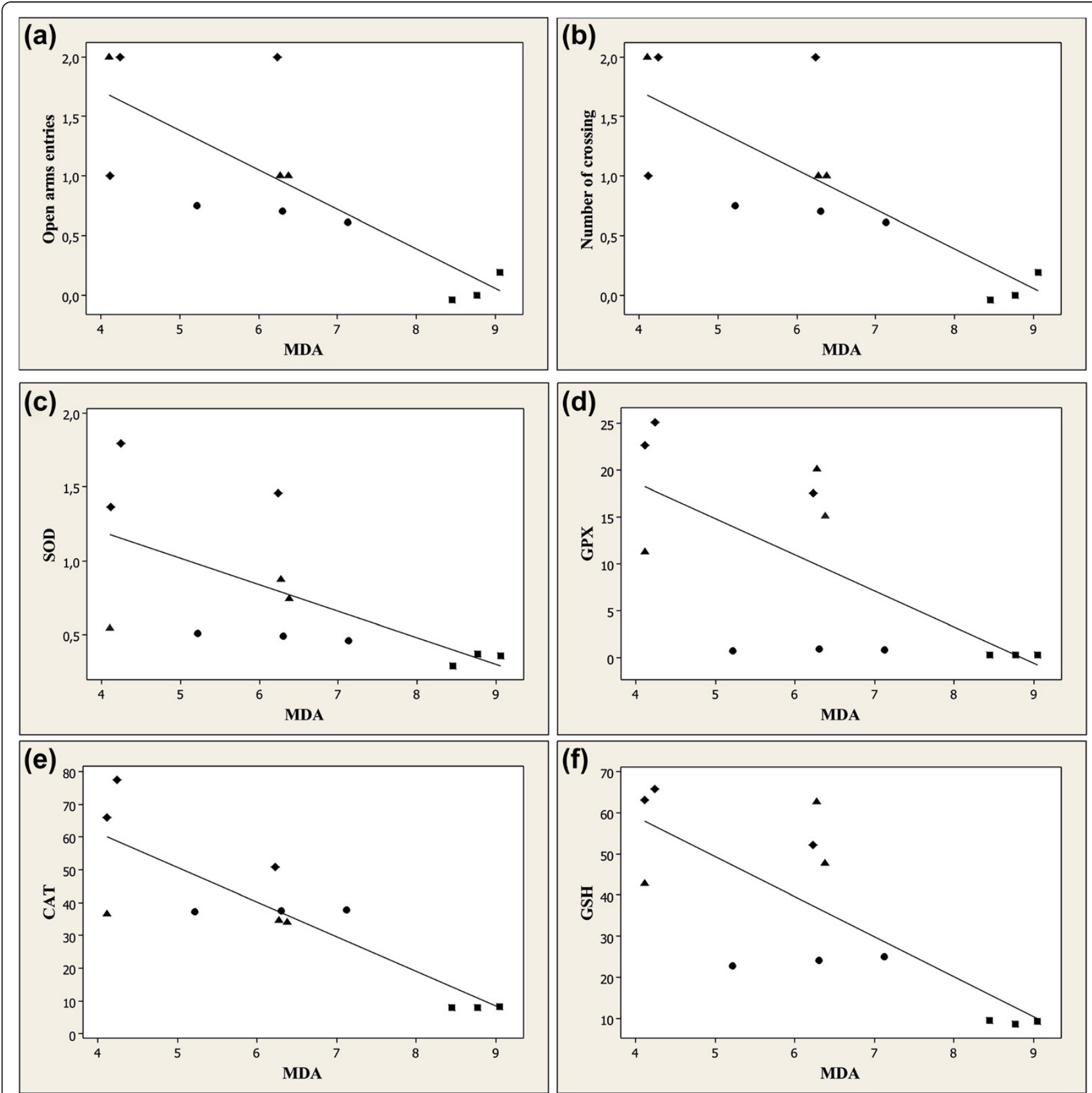

Fig. 5 Pearson's correlation between a the number of entries in the open arms vs. MDA, b the number of crossing vs. MDA, c SOD vs. MDA, d

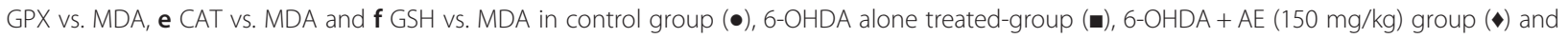
6-OHDA + AE (300 mg/kg) group (

effects. These results are strengthened by the fact that the benzodiazepine diazepam (DZP), well-known as positive standard anxiolytic [37], was used as positive control comparatively to the aqueous extract in all of our experimental conditions. DZP produced significant increases of the number of open-arm entries and in the number of crossing, while the percentage of time spent in the open arms was decreased as compared to control group. These data are consistent with the results of numerous previous studies, which have shown that DZP and other benzodiazepines produce significant anxiolytic effects in a variety of anxiolytic screening procedures, including elevated plus-maze test procedures [38]. The pharmacological action of diazepam enhances the effect of the neurotransmitter GABA by binding to the benzodiazepine site on the $\mathrm{GABA}_{\mathrm{A}}$ receptor (via the constituent chlorine atom) leading to central nervous 


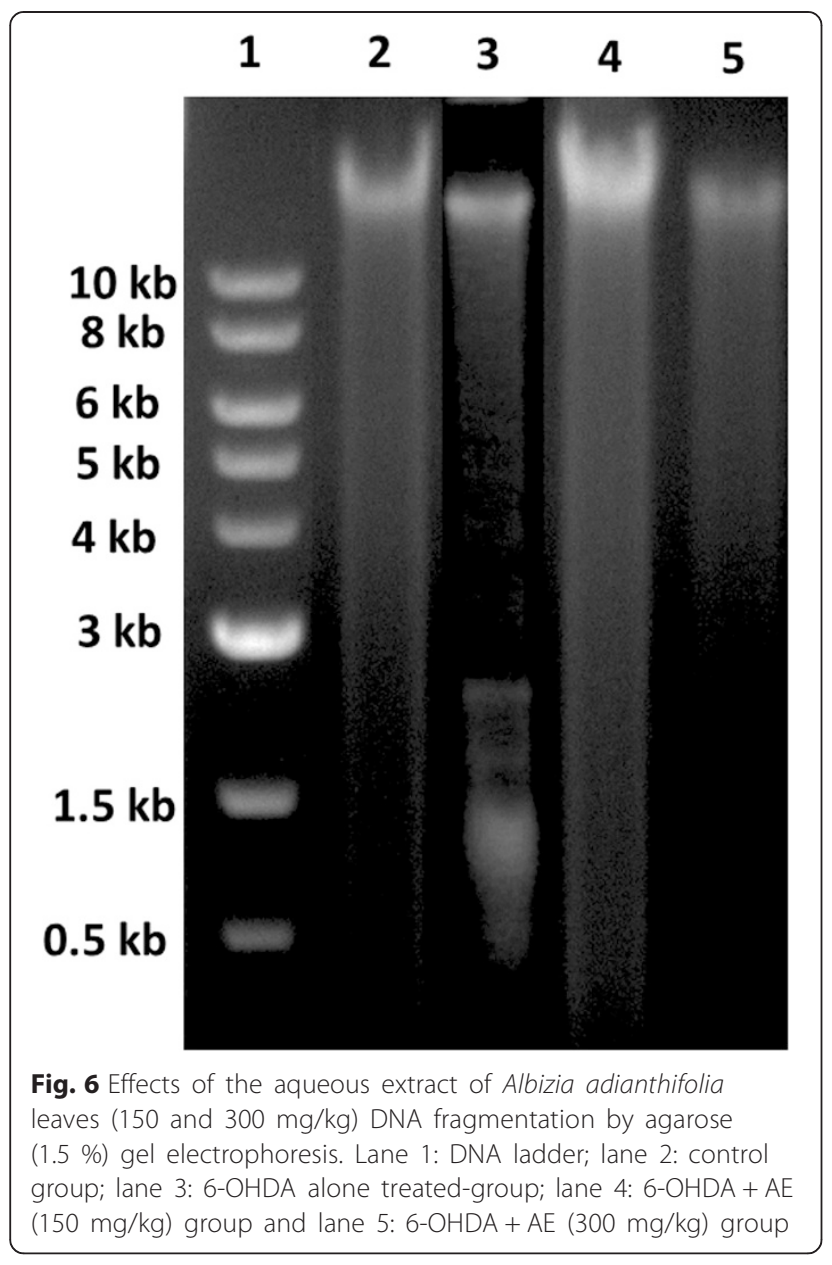

system (CNS) depression. The anxiety indicators in the elevated plus-maze (the percentage of the time spent in the open arms and the number of open-arm entries) showed up being sensitive to the agents which were thought to act via the $\mathrm{GABA}_{\mathrm{A}}$ receptor complex [39].

The anxiolytic-like effects of the aqueous extract could be explained by the presence of apigenin in large amounts, as previously evidenced by HPLC analysis [16]. However, it is suggested that apigenin has a clear anxiolytic-like effect in mice, without evidencing sedation or muscle relaxation effects. This effect could be mediated by the action of GABA receptor complex [40]. In agreement with these reports, our high-apigenin containing aqueous extract has increased anxiolytic-like behavior and exploratory activity in 6-OHDA-treated rats.

The forced swimming test has been validated as a suitable tool for predicting the antidepressant properties of drugs [41]. When rodents are forced to swim in a confined space, after an initial period of struggling, they would become immobile, resembling a state of despair and mental depression. This inescapable stressful situation can be evaluated by assessing different behavioral strategies [42].

Our data suggest that 6-OHDA increased the immobility time in the forced swimming test, a standard behavioral paradigm indicative of depression [34]. These findings are in line with a previous study performed in the 6-OHDA-lesioned rat [43]. Moreover, we found that treatment with the aqueous extract $(150 \mathrm{mg} / \mathrm{kg}$ and $300 \mathrm{mg} / \mathrm{kg}$ ) effectively reverted the increase of the immobility time and prolonged the swimming time displayed by the 6-OHDA-lesioned rats. We used tramadol as a positive control in the aqueous extract assay for all of our experimental conditions. Tramadol has been studied in the forced swimming test in rats, a test developed to predict the antidepressant action of drugs [44]. Tramadol is a unique drug with multiple modes of action. It is a weak agonist of the $\mu$-opioid receptor but it also inhibits the reuptake of serotonin as well as norepinephrine. It is an analgesic and it is also considered as an antidepressant [45]. Also, tramadol exhibited significant effects on the immobility time while swimming time was decreased as compared to control group.

Oxidative stress enhancement also plays a pivotal role in 6-OHDA-neurotoxicity in experimental models of PD [46]. There is increasing evidence that oxidative stress due to increased generation of reactive oxygen species is strongly involved in the pathogenesis of PD, suggesting that pharmacological targeting of the antioxidant machinery may be of benefit in PD therapy [47]. Since 6OHDA leads to the production of both $\mathrm{H}_{2} \mathrm{O}_{2}$ and superoxide radicals, decreasing of SOD activity leads to 6-OHDA-induced toxicity. Similarly, a decrease of GPX activity may be a cause of a decrease in the levels of GSH, because 6-OHDA induced cytotoxicity via $\mathrm{H}_{2} \mathrm{O}_{2}$ intracellular production which can be transformed in reactive hydroxyl radicals and produce cell damage [48]. The aqueous extract of $A$. adianthifolia leaves in the two doses used, reestablished the specific activities of SOD, GPX and CAT, increased GSH level along with decreased lipid peroxidation (MDA level) and protein oxidation (protein carbonyl level) in the amygdala homogenates. The increased activities of SOD, GPX, CAT, GSH level and the decreased levels of protein carbonyl and MDA induced by administration of the aqueous extract of $A$. adianthifolia leaves, implying that this plant extract possesses strong antioxidant property. The antioxidants SOD and GSH have a certain antidepressant effect. Thus, anti-oxidation features in organisms are considered one way to resist depression [49]. The antioxidant effect observed could be attributed to apigenin the only flavonoid that was quantified [16]. Our finding are in line with other studies in which apigenin strongly scavenged the ROS overproduction and provided sufficient antioxidant effect by improving the 
antioxidative enzymes activity [11]. Also, apigenin was found to exert a variety of pharmacological actions on the central nervous system, such as anxiolytic and sedative properties [50]. Therefore, the observed effects of our plant extract could be attributed at least partially to apigenin.

Additionally, when linear regression was determined, a significant correlation between the number of entries in the open arms vs. MDA, the number of crossing vs. MDA, SOD vs. MDA, GPX vs. MDA, CAT vs. MDA and GSH vs. MDA was observed. These results may suggest that the increase of anxiolytic responses within elevated plus-maze and the antioxidant defence along with decrease of lipid peroxidation could be correlated with involvement of the aqueous extract in neuroprotection against 6-OHDA-induced oxidative stress generation in the rat amygdala. Also, we reported the absence of DNA cleavage patterns in the amygdala of the 6-OHDA-treated rats after administration of the aqueous extract, suggesting that the aqueous extract doesn't possesses neurotoxic effects.

Regarding the limitation of our study we can add that there is an indirect behavioral evidence (e.g. rotational behavior) that the lesion worked rather than neurochemistry of the substantia nigra to confirm the size of lesion.

\section{Conclusions}

In summary, the aqueous extract of $A$. adianthifolia leaves has anxiolytic and antidepressant effects, and may confer neuroprotection due to alleviation of oxidative stress in the rat amygdala induced by 6-OHDA injection. Furthermore, administration of the aqueous extract might offer a useful alternative or complementary choice in either the prevention or the treatment of psychiatric condition with relevance for $\mathrm{PD}$.

\section{Competing interests}

The authors declare that they have no competing interests.

\section{Authors' contributions}

GJB conducted the behavioral study; MM conducted biochemical analyses; GJB and HSF have collected the plant and carried out the extraction; LH, GJB, ABD and TD contributed to design, drafting and revision of the manuscript; LH contributed in analyze and interpretation the data; LH provided the reagents and supervised the research. All authors read and approve the final version of the manuscript.

\section{Acknowledgments}

Galba Jean Beppe was supported by Doctoral scholarships Eugen lonescu (2012/2013), Alexandru loan Cuza University of lasi, Romania.

\section{Author details}

${ }^{1}$ Laboratory of Animal Physiology, Faculty of Science, University of Yaoundé I, PO Box, 812, Yaoundé, Cameroon. 'Laboratory of Animal Biology and Physiology, University of Douala, PO Box, 24157, Douala, Cameroon. ${ }^{3}$ Department of Biological Sciences, Faculty of Science, University of Maroua, PO Box, 814, Maroua, Cameroon. ${ }^{4}$ Department of Biology, Alexandru loan Cuza University of lasi, Bd. Carol I, No. 11, Iasi, Romania.
Received: 13 December 2014 Accepted: 13 October 2015

Published online: 19 October 2015

\section{References}

1. Collier TJ, Kanaan NM, Kordower JH. Ageing as a primary risk factor for Parkinson's disease: evidence from studies of non-human primates. Nat Rev Neurosci. 2011;12:359-66.

2. Barone P. Treatment of depressive symptoms in Parkinson's disease. Eur J Neurol. 2011;18:11-5.

3. Schwarz J, Odin P, Buhmann C, Csoti I, Jost W, Wüllner U, et al. Depression in Parkinson's disease. J Neurol. 2011;258:336-8.

4. Leentjens AFG, Dujardin K, Marsh L, Richard IH, Starkstein SE, MartinezMartin P. Anxiety rating scales in Parkinson's disease: A validation study of the Hamilton anxiety rating scale, the Beck anxiety inventory, and the hospital anxiety and depression scale. Movement Disord. 2011;26:407-15.

5. Chaturvedi RK, Shukla S, Seth K, Chauhan S, Sinha C, Shukla Y, et al. Neuroprotective and neurorescue effect of black tea extract in 6hydroxydopamine-lesioned rat model of Parkinson's disease. Neurobiol Dis. 2006;22:421-34.

6. Hritcu L, Ciobica A, Artenie V. Effects of right-unilateral 6-hydroxydopamine infusion-induced memory impairment and oxidative stress: relevance for Parkinson's disease. Cent Eur J Biol. 2008;3:250-7.

7. Akirav I, Maroun M. The role of the medial prefrontal cortex-amygdala circuit in stress effects on the extinction of fear. Neural Plasticity. 2007; 2007:30873.

8. Chen L, Liu J, Zhang QJ, Feng JJ, Gui ZH, Ali U, et al. Alterations of emotion, cognition and firing activity of the basolateral nucleus of the amygdala after partial bilateral lesions of the nigrostriatal pathway in rats. Brain Res Bull. 2011;85:329-38.

9. Kitayama T, Onitsuka Y, Song L, Morioka N, Morita K, Dohi T. Assessing an eating disorder induced by 6-OHDA and the possibility of nerve regeneration therapy by transplantation of neural progenitor cells in rats. Nihon Shinkei Seishin Yakurigaku Zasshi. 2007;27:109-16.

10. Hefco V, Yamada K, Hefco A, Hritcu L, Tiron A, Nabeshima T. Role of the mesotelencephalic dopamine system in learning and memory processes in the rat. Eur J Pharmacol. 2003;475:55-60.

11. Patil SP, Jain PD, Sancheti JS, Ghumatkar PJ, Tambe R, Sathaye S. Neuroprotective and neurotrophic effects of apigenin and luteolin in MPTP induced parkinsonism in mice. Neuropharmacology. 2014;86:192-202.

12. Perier C, Vila M. Mitochondrial Biology and Parkinson's Disease. Cold Spring Harb Perspect Med. 2012;2:a009332.

13. Stafford Gl, Pedersen ME, van Staden J, Jäger AK. Review on plants with CNS-effects used in traditional South African medicine against mental diseases. J Ethnopharmacol. 2008;119:513-37.

14. Kim W-K, Jung JW, Ahn NY, Oh HR, Lee BK, Oh JK, et al. Anxiolytic-like effects of extracts from Albizzia julibrissin bark in the elevated plus-maze in rats. Life Sci. 2004;75:2787-95.

15. Jung Y-H, Ha R-R, Kwon S-H, Hong S-I, Lee K-H, Kim S-Y, et al. Anxiolytic effects of Julibroside C1 isolated from Albizzia julibrissin in mice. Prog Neuropsychopharmacol Biol Psychiatry. 2013:44:184-92.

16. Beppe G, Dongmo A, Foyet H, Tsabang N, Olteanu Z, Cioanca O, et al. Memory-enhancing activities of the aqueous extract of Albizia adianthifolia leaves in the 6-hydroxydopamine-lesion rodent model of Parkinson's disease. BMC Complement Altern Med. 2014;14:142.

17. Sanjay K. Saponins of Albizia lebbek in Alzheimer's and Parkinson's disease. IJMPR. 2003;19:42-8.

18. Paxinos $\mathrm{G}$, Watson C. The rat brain in stereotaxic coordinates. 6th ed. London: Academic Press; 2007.

19. Franklin AE, Engeland CG, Kavaliers M, Ossenkopp K-P. Lipopolysaccharideinduced hypoactivity and behavioral tolerance development are modulated by the light-dark cycle in male and female rats. Psychopharmacology. 2003;170:399-408.

20. Herrera-Marschitz M, Arbuthnott G, Ungerstedt U. The rotational model and microdialysis: Significance for dopamine signalling, clinical studies, and beyond. Prog Neurobiol. 2010;90:176-89.

21. Rajendra Kopalli S, Koppula S, Young Shin K, Noh S-J, Jin Q, Yeon Hwang B, et al. SF-6 attenuates 6-hydroxydopamine-induced neurotoxicity: An in vitro and in vivo investigation in experimental models of Parkinson's disease. J Ethnopharmacol. 2012;143:686-94. 
22. Hayashi $Y$, Sogabe S, Hattori Y, Tanaka J. Anxiolytic and hypnotic effects in mice of roasted coffee bean volatile compounds. Neurosci Lett. 2012;531:166-9.

23. Rodgers RJ, Dalvi A. Anxiety, defence and the elevated plus-maze. Neurosc Biobehav Rev. 1997;21:801-10.

24. Campos M, Fernandes E, Ferreira J, Santos AS, Calixto J. Antidepressant-like effects of Trichilia catigua (Catuaba) extract: evidence for dopaminergicmediated mechanisms. Psychopharmacol (Berl). 2005;182:45-53.

25. Winterbourn C, Hawkins R, Brian M, Carrell R. The estimation of red cell superoxide dismutase activity. J Lab Clin Med. 1975:85:337.

26. Sharma M, Gupta Y. Chronic treatment with trans resveratrol prevents intracerebroventricular streptozotocin induced cognitive impairment and oxidative stress in rats. Life Sci. 2002;7:2489-98.

27. Sinha A. Colorimetric assay of catalase. Anal Biochem. 1972;47:389-94

28. Fukuzawa A, Tokumura A. Glutathione peroxidase activity in tissues of vitamin E-deficient mice. J Nutr Sci Vitaminol (Tokyo). 1976;22:405-7.

29. Oliver C, Ahn B, Moerman E, Goldstein S, Stadtman E. Age-related changes in oxidized proteins. J Biol Chem. 1987;262:5488-91.

30. Luo S, Wehr N. Protein carbonylation: avoiding pitfalls in the 2,4-dinitrophenylhydrazine assay. Redox Rep. 2009;14:159-66.

31. Ohkawa H, Ohishi N, Yagi K. Assay for lipid peroxides in animal tissues by thiobarbituric acid reaction. Anal Biochem. 1979;95:351-8.

32. Smith P, Krohn R, Hermanson G, Mallia A, Gartner F, Provenzano M, et al. Measurement of protein using bicinchoninic acid. Anal Biochem. 1985;150:76-85.

33. Ausubel FM, Brent R, Kingston RE, Moore DD, Seidman JG, Smith JA, et al. Current Protocol in Molecular Biology. New York: Wiley-Interscience; 2002.

34. Bonito Oliva A, Masini D, Fisone G. A mouse model of non-motor symptoms in Parkinson's disease: focus on pharmacological interventions targeting affective dysfunctions. Front Behav Neurosci. 2014;8:290.

35. Kumar D, Bhat ZA. Apigenin 7-glucoside from Stachys tibetica Vatke and its anxiolytic effect in rats. Phytomedicine. 2014;21:1010-4.

36. Kish SJ, Tong J, Hornykiewicz O, Rajput A, Chang L-J, Guttman M, et al. Preferential loss of serotonin markers in caudate versus putamen in Parkinson's disease. Brain. 2008;131:120-31.

37. Mansouri MT, Soltani M, Naghizadeh B, Farbood Y, Mashak A, Sarkaki A. A possible mechanism for the anxiolytic-like effect of gallic acid in the rat elevated plus maze. Pharmacol Biochem Behav. 2014;117:40-6.

38. Adebesin IF, Akindele AJ, Adeyemi OO. Evaluation of neuropharmacological effects of aqueous leaf extract of Albizia glaberrima (Leguminosae) in mice. J Ethnopharmacol. 2015;160:101-8.

39. Emamghoreishi M, Khasaki M, Aazam MF. Coriandrum sativum: evaluation of its anxiolytic effect in the elevated plus-maze. J Ethnopharmacol. 2005;96:365-70.

40. Savić MM, Kukić JM, Grayer RJ, Milinković MM, Marin PD, Divljaković J, et al. Behavioural characterization of four endemic Stachys taxa. Phytother Res. 2010;24:1309-16.

41. Cioanca O, Hritcu L, Mihasan M, Hancianu M. Cognitive-enhancing and antioxidant activities of inhaled coriander volatile oil in amyloid $\beta(1-42)$ rat model of Alzheimer's disease. Physiol Behav. 2013;120:193-202.

42. Tolardo R, Zetterman L, Bitencourtt DR, Mora TC, de Oliveira FL, Biavatti MW, et al. Evaluation of behavioral and pharmacological effects of Hedyosmum brasiliense and isolated sesquiterpene lactones in rodents. J Ethnopharmacol. 2010;128:63-70.

43. Drui G, Carnicella S, Carcenac C, Favier M, Bertrand A, Boulet S, et al. Loss of dopaminergic nigrostriatal neurons accounts for the motivational and affective deficits in Parkinson's disease. Mol Psychiatry. 2014;19:358-67.

44. Jesse CR, Bortolatto CF, Savegnago L, Rocha JBT, Nogueira CW. Involvement of L-arginine-nitric oxide-cyclic guanosine monophosphate pathway in the antidepressant-like effect of tramadol in the rat forced swimming test. Prog Neuropsychopharmacol Biol Psychiatry. 2008;32:1838-43.

45. Caspani O, Reitz M-C, Ceci A, Kremer A, Treede R-D. Tramadol reduces anxiety-related and depression-associated behaviors presumably induced by pain in the chronic constriction injury model of neuropathic pain in rats. Pharmacol Biochem Behav. 2014;124:290-6.

46. Baluchnejadmojarad T, Roghani M, Mafakheri M. Neuroprotective effect of silymarin in 6-hydroxydopamine hemi-parkinsonian rat: Involvement of estrogen receptors and oxidative stress. Neurosci Lett. 2010;480:206-10.
47. Zare K, Eidi A, Roghani M, Rohani A. The neuroprotective potential of sinapic acid in the 6-hydroxydopamine-induced hemi-parkinsonian rat. Metab Brain Dis. 2015;30:205-13.

48. Foyet HS, Hritcu L, Ciobica A, Stefan M, Kamtchouing P, Cojocaru D. Methanolic extract of Hibiscus asper leaves improves spatial memory deficits in the 6-hydroxydopamine-lesion rodent model of Parkinson's disease. J Ethnopharmacol. 2011;133:773-9.

49. Zafir A, Ara A, Banu N. In vivo antioxidant status: A putative target of antidepressant action. Prog Neuropsychopharmacol Biol Psychiatry. 2009:33:220-8.

50. Avallone R, Zanoli P, Puia G, Kleinschnitz M, Schreier P, Baraldi M. Pharmacological profile of apigenin, a flavonoid isolated from Matricaria chamomilla. Biochem Pharmacol. 2000:59:1387-94.

\section{Submit your next manuscript to BioMed Central and take full advantage of:}

- Convenient online submission

- Thorough peer review

- No space constraints or color figure charges

- Immediate publication on acceptance

- Inclusion in PubMed, CAS, Scopus and Google Scholar

- Research which is freely available for redistribution 